Aaron Eldridge

\title{
“I Long For My Mother's Bread”: Poetry as Integrative, Historical Practice in the Palestinian Context
}

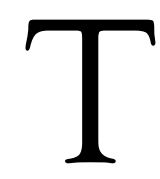

his paper is an adaption of a longer investigation of the relationship between politics and poetry in the Palestinian context, focusing on the work of Mahmoud Darwish. For this selection, I have adapted the sections pertaining to the efficacy of poetry in the context of historical events-specifically the traumatic history of the Palestinians. It is my argument that artistic practices like poetry act primarily as a means of narrative creation that skillfully integrate the experiences of the poet and thus negotiate the experiences of the listeners in order to create new meaning. This dialogue between audience and poet creates a persuasive and novel movement within the conceptual field; thinking about something in terms of something else (metaphor). This has the effect of making the poet an intractable source of historical meaning. The questions of the past, a dizzying array of dissonant occurrences, fractured experiences, and selected memory, find cogency within the poetic form. This artistic formation only gains this cogency through a precise system of cognitive faculties, which are shared by both poet and audience. The poetry of Mahmoud Darwish acts as a means of understanding history in the context of the present; creating an integrated narrative-history, which has important implications on experience, implicating present action through a 'reading' of the past. 
`āḥinnu `ilā knubzi ’ummī

wa-qahwati ${ }^{\mathrm{u}} \mathrm{ummi}$

wa-lamsati ${ }^{\circ}$ ummī

wa-takburu fiyya 'tt-ṭufülatu

yawman calā șadri yawmi

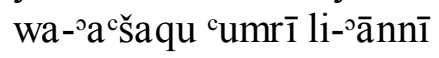

`idāa muttu

จākjalu

min damci ${ }^{\supset} u m \bar{\imath}$
I long for my mother's bread

And my mother's coffee

And my mother's touch

My childhood grows within me

Day after day

I love my life because

If I died,

I would be embarrassed

by my mother's tears

This verse is being chanted over the coffin of Mahmoud Darwish, sung by hundreds of Palestinians. ${ }^{1}$ His coffin is slowly processed through the countryside; Palestinian flags are carried by the pursuing crowd. Draped with the national flag and the Palestinian kaffiya, the coffin bears flowers and pictures of the poet paired with the phrase sanakūn yūmi mā nurīd; one day we will be as we wish. The procession works its way up a winding slope to the mountainside quarry, piles of white stone abound. Here, several men begin to set up a makeshift barbed wire fence, the poles of which are held up by a collection of stones. In the center of this space, the coffin is placed; rocks are slowly stacked, surrounding it. A woman with a microphone, accompanied by an 'îd player, leads the hundreds of mourners to the melodized rendition of Darwish's poem, which was originally sung by Marcel Khalife, a famous Lebanese singer and friend of Darwish. The verses are repeated over and over as a rock shrine is constructed around the casket of the poet. Much to my own surprise, watching a video of this event, is that this is not the funeral

\footnotetext{
1 This event was recorded on video. URL: http://www.youtube.com/watch?feature=player_embedded\&v=ZSm10aYF--c\#!
}

Accessed: February 2013 
of the poet; in fact the coffin is empty. The casket with the actual body of Mahmoud Darwish is miles away in Ramallah. Instead, this memorial is being held in present-day Israel, near the once-town of al-Birwa, the birthplace of Mahmoud Darwish.

We decided to choose al-Birwa, which is represented by the village quarry and represents the 'right of return' for us. In this moment is the continuation of the life and legacy of Mahmoud Darwish; the legacy of resistance and challenge, affecting the life of the homeland (Funeral Participant). ${ }^{2}$

The funeral with the actual body of Mahmoud Darwish was in Ramallah, the de facto capital of the Palestinian Authority. Aside from Yasser Arafat in 2004, Darwish was the only individual to receive the equivalent of a state funeral. In 2008 his body was airlifted from the United States, where Darwish had died from complications with heart surgery, and then from Jordan to Palestine. Before his arrival, hundreds of Palestinians kept an all-night vigil where many of his poems were read aloud. Once his body arrived, an honor guard with a military band marched his flag-draped coffin to the back of pickup truck, which was slowly led in procession through the streets of Ramallah, headed by President Mahmoud Abbas, leader of al-Fatah and of the Palestinian Authority, the semiautonomous governing body of the Palestinian territories: East Jerusalem, the West Bank, and Ghaza. The procession was followed by thousands of Palestinians, holding flags and pictures of the poet

\footnotetext{
2 Ibid. Translated from Arabic by the author.
} 
with poetic verses emblazoned across them, many with the phrase "there is much on this land worth living for". ${ }^{3}$

Unlike the symbolic funeral, which sang a rendition of Khalife's work, Marcel Khalife himself, dressed all in black and in tears, sang the funeral dirge ās-salāmmu calayyki; peace be upon you. Many foreign dignitaries attended, as well as prominent intellectuals. Ali Qleibo, a fellow poet said, "He felt the pulse of Palestinians in beautiful poetry. He was a mirror of the Palestinian society" (Al-Jazeera). Mahmoud Abbas gave a speech saying, "The passing of our great poet Mahmoud Darwish, the lover of Palestine, the pioneer of the modern Palestinian cultural project and brilliant national leader, will leave a great gap in our political, cultural, and national lives" (Lynfield). Even the leader of Hamas, the party which heads the quasi-government in the Ghaza strip, (the party that Darwish often spoke against) spoke well of the poet; "Palestinian arts has lost through Mahmoud Darwish's death one of its most essential treasures" (Lynfield).

Once the procession had ended, Darwish's coffin, held aloft by six Palestinian guards, was solemnly processed down a velvet carpet to the Palestinian Cultural Palace. His body was interred on a nearby slope, facing Jerusalem, where Darwish had last publicly read his poetry. The writing on his tombstone reads:

\footnotetext{
3 These events were recorded on video. URL: http://www.youtube.com/watch?feature=endscreen\&v=pZ-S4m0sjAQ\&NR=1 URL: http://www.mahmouddarwish.com/ui/english/ShowContent.aspx?ContentId=19 Accessed: February 2013
} 
calā al-`ārd

saydati 'l-oārọ

mā yustaḥaq al-ḥayā
On earth

Beautiful Earth

What makes life worth living

As a ritualized event, the funeral(s) of Mahmoud Darwish could merit an entire academic work in itself. However, my investigation focuses on precisely what I believe garners an individual this type of collective treatment. Drawn from the description of the events, it is clear that Darwish's own poetic verses permeated the ritual action; on posters, in oral performance, through speeches, in song, and finally etched in stone. Examining the symbolic funeral of Darwish, it is clear that there is a sense that people felt an emotional obligation toward the man himself; there exists a kind of conflation of poet and poetry. This transposition of emotional feelings from art to artist is not unusual, though it is informative. The burial of Mahmoud Darwish in this sense qualifies as a social performance, in that individuals are participating in a collective affirmation of their own identity, Benedict Anderson's imagined community, the metonym for which is Darwish himself. The catalyst for this social performance is a complex contextual array of meaning; Darwish, his poetry, conflate into a space in which the Palestinians participate and actively construct. There is also a sense of the funeral as an existential transposition, which is actualized upon the performers themselves. If Darwish acts as a metonym for the Palestinians, burying him in their homeland is then an act of repossession; returning him returns them metaphysically. It is not enough for the participants to physically inhabit the land today (likely some do, being Arab Israelis) but to return in a metaphysical sense to the land as it was as remembered- a paradisal state. Thus, the seamless 
mixing of funeral rites and poetry (old partners) which, as dialogic negotiation, create new meanings for the participants. These instantiations are conceptual formations which adhere to an idealized whole and indicate a type of integrative practice, linking the ritual social action to transcendent truth. So what we see on a mountainside slope in Israel is conceptualized as a metaphysical act, it extends beyond the physicality of the moment and attains novel meaning; the actualization of transcendence itself. Regardless of idealized and romanticized notions of the transcendence of art, the symbolic burial of Darwish is a political act, in that it claims a real historical continuity against an institution (the Israeli state), which would deny such a claim. The very fact that Darwish's burial symbolizes the 'right of return' is evidence for the very real political action is at once physical and metaphysical.

This becomes more obvious when considering the burial of Darwish in Ramallah. The fact that Darwish is being interred in a state funeral (or a near approximation of one) is itself an indication of his political importance. Being called a "mirror of Palestinian society" brings to mind the notion of the individual as a metonym for the nation, much like in the symbolic funeral. In both cases, this is an example of significant politicization because it links Darwish inexorably with the fate of the state. Regardless, to be called a metonym of the nation is not merely manipulative rhetoric by Abbas. There is a sense in which Mahmoud Darwish was a real political leader; he took part in political actions with the PLO for decades, and was a prominent figure who fought for the political unity of Palestine. In either case, there seems to be both a physical (political) and metaphysical (transcendent/artistic) performative response to Mahmoud Darwish, though this tension is hardly distinguishable in the realities of practice. 
It is interesting in both cases to consider the works chosen to be part of the performative aspects of both funerals. Khaled Mattawa, classifies the earliest period of Darwish's writing as the "Lover of Palestine”, a period where Darwish develops the Palestine subject as victim. According to Mattawa, it is these poems that are most often sung and cited by the PLO and Palestinian nationalist causes generally. Later works, which shifted to prose and became more philosophical, are less known and less brought into public discourse. The reasons for this, apart from the earliest poetry being the most nationalistic and thus most propagated by those with the ability to spread such work, it that it highlights the experiential memory of these events. It tells that though both focus on history, it is in the visceral language of the former that individuals connect with in a striking way.

Social Reconstruction as a Performative Catalyst: Palestinian History

Certain events create a stronger predilection for emergent culture, which is defined as a type of reconceptualization of cultural norms within the framework of the preexisting set of cultural resources. Thus, this shift is predicated upon previous normative culture, but shows fundamental shifts in ideology and practice. It is evident that certain events, ones which have massive impact on society in general ${ }^{4}$, will more strongly lead to a general restructuring of practices and institutions. Steven Caton argues that there are several social contexts which predicate emergent culture; "contexts of socio-economic change, in which the traditional system does not serve as an adequate model or precedent for social action...[and]

${ }^{4}$ More specifically, it is the dominant institutions, practices, and ideologies of a particular society. 
contexts of social reconstruction (for example, after a natural disaster or warfare)" (261). Such examples were (and still are) prevalent in the Palestinian situation and make it necessary to consider artistic forms like that of Darwish's poetry in this context. The shifts in cultural practices are evident in communicative acts, which are themselves the utilization and expression of changing norms. Importantly, this change does not begin ex nihilo, but reapplies fluid conceptual formation to an already present systems of thought and practice.

In fact, it may be possible to apply Victor Turner's notion of communitas and liminality in such a situation. Though typically applied to notions of ritual, social reproduction/cohesion, and effervescence, this is not the limits of the concept's usefulness. Walter Armbrust in his work on the Egyptian revolution has argued that an understanding of these events in terms of liminality is extremely fruitful, in so far as prominent structures shift to the background, anti-structure prevails, and there is potential for social inversion, usurpation, and fundamental change. Importantly this experience of liminality is generalizable to the society, rather than a particular class or group. In such a frame, the community, in a moment, may attend to such anti-structure and communitas, creating the potential to reify moments of intense change and allow them to become manifest as enacted memory. However, the way this cohesion is formed is not a simple matter of memory. Social memory ${ }^{5}$, in very concrete forms, through specific relations of power,

\footnotetext{
${ }^{5}$ David Berliner has cited many problems associated with a typified notion of social memory, as he argues; when memory becomes everything, what then is there that is not memory? As such, I do not wish to stress too strongly a notion that memory of the Palestinian past is found in the very fabric of Palestinian society there is a much more direct way to accomplish this. The concrete cognitive memories of past events, propagated and reified through discourse, cultural
} 
are the means by which such communitas is recalled and remade, a hardly objective occurrence but one which is dialogic and competed over.

In such a situation, poetry becomes an agent of potentiality and engages in a type of narrative, which is fundamentally anchored in conceptual movement. Thus, emergent cultural practices are the product of liminality, in that social disorder leads to a renegotiation of previously structured aspects, both discursive and institutional. What kinds of events necessitate this rapid restructuring? In this case study, the history of Palestine has several events which were times of massive social deconstruction, disruptive to the socioeconomic and cultural life of all Palestinians, making the effect all the more salient.

Two events in particular can be highlighted: al-Nakba (The Tragedy', the creation of the state of Israel in 1948 and subsequent Palestinian diaspora) and The June War of 1967 (the occupation of all Palestine by Israel). These non-bounded events become temporally and spatially demarcated and persist in the public consciousness as real social objects. They garner a sociality, becoming immanent through discursive cultural practice. The creation of a hermetic historical event is vital to an understanding of its use as an experiential narrative within discourse.

\section{al-Nakba-1948}

In November 29th, 1947, the UN voted in favor of a partition of Palestine in an Arab and Jewish state (Cleveland \& Bunton). The Palestinians were left out of negotiation, both in the initial decision 
and in the finer issues of partition. British refusal to assist in the implementation of the partition resulted in communal struggles: Jewish Haganah (paramilitary) forces attempted to forcibly remove Palestinians from UN allotted Jewish territory, encountering predictable resistance. The most infamous case was the massacre at Dayr Yassin', a village near Jerusalem, in which "between 110 and 240 [Palestinian] men, women, and children were butchered, and the bodies of many were stuffed in the village well" (Gelvin 213). This atrocity was one among many and both sides quickly escalated into a display of systemic violence. Massacres like Dayr Yassin created a mass panic, which was further pushed by the Haganah's 'Plan D'. Plan D was a government policy to "provide for the conquest and permanent occupation, or leveling of Arab villages and towns" (Cleveland \& Bunton 268). This policy was instigated in all new Israeli territory and the Arab towns that bordered it, as part of policy to create a homogenous Jewish state with secure boundaries. The culmination of these actions resulted in a mass exodus of over 700,000 Palestinian refugees, with only 160,000 remaining in Israeli territory. Within a year armistices were signed between all belligerent members, the surrounding Arab states and Israel. The Palestinian lands were divided amongst the Israelis, the Egyptians (who took control of the Gaza strip) and Transjordan (who took control of the West Bank and East Jerusalem). By 1949 the Palestinian people were effectively stateless, with many occupying long-term refugee camps in neighboring states.

\footnotetext{
${ }^{6}$ Dayr Yassin became one of the most evoked events in the Nakba, it often is cited as proof to this day of the uncompromising and brutal character of the Israel program.
} 


\section{The June War-1967}

The 1967 June War (also known as the Six-day war), involved an aggressive and powerful attack against Syria, Jordan, and Egypt which saw Israel gain control of the entirety of Palestinian lands. Now millions of Palestinians were under the direct control of the Israeli government, being ruled "in an often arbitrary manner" (Cleveland \& Bunton 345). The major effects of the June War were to delegitimize the wider Arab world for Palestinians and to call into question their desire to affect a solution to diaspora and occupation. The June war also served to solidify Palestinian resistance movements, motivating them to assume responsibility for their own liberation. The most important of these groups was al-Fatah, whose leader Yasser Arafat would become the chairman of the PLO from 1969-2004. These movements, especially in their early forms, occurred primarily outside of the occupied territories.

For the Palestinians living in Israeli occupied territory, they persisted as a liminal people, living under military rule for the first ten years of the occupation, being neither driven from the territory (though Jewish settlement in key areas was ongoing), nor being allowed independence. This changed with the election of Menachem Begin and the Likud party, which, following 1977, began the religious settlers movement which favored total annexation of the occupied territories. This settlement strategy was deliberate and calculated; it sought to create a substantial Jewish population within the occupied territories so as to make any withdrawal impossible. Moreover, settlement was encouraged in areas where there was a large Palestinian population, both as a means of creating isolation and to prevent unity. In addition to political annexation, the Likud government sought to create a dependency of Palestinian economics 
on the Israeli state. Workers were made to be dependent on Israeli employers and duties were leveled against Palestinian growers to export their product to Israel. Military oppression was common, with the imprisonment and detainment of hundreds of activists, as well as 'collective punishment' in the form of house arrests and business closures. These effects were compounded by "the aggressive actions of some settlers, who practiced their own brand of vigilante justice...the net effect was the simultaneous demoralization and radicalization of the Arab inhabitants" (Cleveland \& Bunton 366).

Mahmoud Darwish would endure both these events as lived experiences. Born in al-Birwa in 1941, his parents were landowning peasants. Though his mother was illiterate, his grandfather taught him to read. In 1948, Darwish and his family fled the region, to Lebanon, Jezzin and Damour. A year later, Darwish and his family snuck back into what was now Israel and found their village destroyed. They settled in a nearby Galilean town called Dayr al${ }^{\circ}$ Asad. There, Darwish grew up in a school system that was predominantly Hebrew; a language he would soon become fluent in. As a young man, Darwish moved to Haifa and became editor of alJadid, an Israeli Communist party paper, where he published his first works (including those cited in this paper). In 1970, he attended the University of Moscow for a year until moving to Egypt and then Lebanon. In 1973 he joined the PLO party and was subsequently banned from entry into Israel and the occupied territories.

The effects of the 1948 war and subsequent occupation in 1967 were pronounced and starkly destructive. When we consider that the Palestinians were not only facing heavy social adaptation, but the very extinction of their society, it is clear how dramatic a new emergent culture would be, negotiated in terms of national identity and experiential narrative. The effect of these events leads to the 
reification communitas. In a helpful definition of how this is accomplished, Gunther Kress argues that 'community' "does not depend on identity of experience or knowledge but rather on a sufficient degree of recognition of the similarity of a shared event...the result is the existence, even if just for a moment, of 'community'; that may or may not develop into a more permanent affective and social connection" (372). Thus, a mutually recognizable similarity in qualitative (not aggregated) experience predicates the building of new social relations. As such, these events create a predilection for new social affinities, which become deeper with integrative devices like poetry to enshrine an experiential bond; the poetry of Darwish builds on the initial recognition of the shared events of al-Nakba and 1967. In this sense, these events can be considered definitive, because they enter the public conscious as bounded spatial-temporal events, rooted in recognition of mutual experience. They gain an authority in the public sphere through acts like poetry which cement the experiential point of existential contact. Arguments on interpretation (the signification of meaning) will no doubt vary, but by their very argument they reify and reaffirm the event's existence.

The diaspora and subsequent derisive Israeli intervention show a society that was completely fragmented, necessitating a stronger understanding of history: the questions 'what happened?', 'what is happening?', and 'what will happen?' all become vital to a holistic understanding of a situation which was unprecedented. From this point, it seems clear that the socio-cultural endeavors like art would be part of a new program of normative practice. The ability of works like poetry to lend themselves to an understanding of these events, 
and to offer a solution or a vision of the future, are pivotal when we consider when and why poetry becomes an effective social act.

Poetry as Art: Power, Persuasion, and Skill

Poetry, like narrative, consists of a collection of metaphors, by which I mean a collection of predications about the world. James Fernandez gives the definition of metaphor as, "a strategic predication upon an inchoate pronoun (an I, a you, a we, a they) which makes a movement and leads to performance...The metaphors in which we are interested make a movement. They take their subjects and move them along a dimension or a set of dimensions" (Fernandez 8, 12). If we are to take this definition of poetry seriously, we see that the given contextual historical reality of a culture, "n dimensions...quality space" (Fernandez 1986, 10), is the space within which text-utterances shift about. This environment, far from being a neutral conceptual/performative ground, is one of intense heteroglossia; there is a multitude of socio-idealogical dialogues that interact with one-another in a very complex way. Every utterance constitutes part of this dialogue, directly or indirectly, "The authentic environment of an utterance, the environment in which it lives and takes shape, is dialogized heteroglossia, anonymous and social as language, but simultaneously concrete, filled with specific content and accented as an individual utterance" (Bakhtin 272). Bakhtin insists on the complex array of dialogic referents that come to the fore of any utterance, text or oral. The importance of the contextual space in a culture, and the inherently dissonant discourses, cannot be disregarded when undergoing an analysis of the efficacy of certain predications within that space. If we grant that poetry makes predications upon the world, how do we account for its success? How does poetry move individuals along cultural continua? 
How does the poetry of Mahmoud Darwish create such a strong performative catalyst as to merit a state and symbolic funeral, collectively performed by thousands of people?

I define efficacy as: the power to persuade an individual to accept the movement of an inchoate pronoun towards a specific set of referential continua. During an interview, Darwish stated, "Poetry needs space for contemplation beyond the present moment. It also needs disengagement from the conditions of the present to allow the poet to link the present moment with the larger issues. He must have the possibility of connecting the daily with the metaphysical" (Shehadeh). Darwish himself sees his work within a wider coherent whole, a larger metaphysical representation of idiosyncratic, present reality. From this it may be argued that artistic efficacy derives precisely from the ability to make the physical metaphysical; the speech acts moves from being merely a set of sounds to a social act that works within the larger cultural space, effectively drawing together dissonant, heteroglossic fields, into a single coherent entity.

An explanation of this effect's actualization can be found in the work of Gregory Bateson, who posits that art, "is somehow expressive of something like grace or psychic integration...the success of this expression might well be recognizable across cultural barriers" (Bateson 128). This integration is that of the conscious and unconscious elements that make up the human psyche. Bateson makes a strong argument for the unconscious and conscious fulfilling crucial interdependent roles; the unconscious is primarily economical in that it fulfills function that could not be accomplished in the conscious mind, both quantitatively (the sheer amount of data and conceptual associations is untenable for the working consciousness) and qualitatively (Bateson gives the example of a TV being made up 
of pixels that only give a clear picture when integrated, likewise our sensory input requires an interpretation of unconscious conceptual associations). Thus, a large part of our experience works within the unconscious realm, which is incapable of being reduced to that of the conscious. Art, as a skillful form, succeeds in the integration of both elements. Skill is crucial to the artistic endeavor, as only skill can give form to an unconscious expression, being itself a form of unconscious knowing. Thus skill, Bateson argues, is incapable of being made perfectly conscious - rationalized and made cognizant. That is, if the poetic form reveals something in its style, because of unconscious elements of skill possessed by the poet, it is impossible to realize them consciously, to explain it in its totality, either by the poet or the audience.

An explanation of how human skill becomes subsumed into the unconscious is found in the work of Michael Polanyi. Like Bateson, Polanyi argues that two epistemological modes exist; tacit and explicit knowledge (akin to Bateson's unconscious and conscious). These modes are interdependent upon one another, "a wholly explicit knowledge is unthinkable" (Polanyi 144). Polanyi argues that the subsumation of skill occurs when a human being stops attending to object and begins attending from that object, "A set of sounds is converted into the name of an object by an act of tacit knowing which integrates the sounds to the object to which we are attending...we attend from them (or through them) to the object to which they are integrated" (Polanyi 145). Skill demonstrates this tacit knowing in that it is a form of indeterminate knowledge; I know how to drive a car, yet I do not know how I coordinate my body to perform such a complex task. Skill, the ability to move between the attendance from an object and to one, occurs with the interiorization of that object within oneself. This occurs by neither mechanical nor magical 
means, but seemingly a hybrid of the two. It is mechanical in the sense that repetitive learning is required; long hours of mental and physical practice help to develop a skill. However, this skill, once obtained, finds itself to be greater than the sum of its parts. To learn a skill does not constitute the entirety of that skill, which now has a generative quality that is only tacitly known. An integral part of that skill's performance is subsumed into the individual. In this sense there is an interesting dilemma (which Bateson also mentions), that we can recognize the existence of tacit knowledge, but have no means by which to explain its content.

In a very important sense then, skill becomes an integrative practice in that it is the subsumation of an ordering, or manipulation, of fractal parts. These parts attain to some kind of tacitly known integration within the skillful mind, in our case, the artist. In this sense, art becomes effective in its contextual circumstances, not from its content per se, but from its skillful integration of that content. Poetry can be considered a meta-message because it relies on faculties that are outside the conscious element of communication. If art is a message, what is the message about? The message is an integrated expression of experience. The content of this message, for Darwish, consists of the events described earlier, in reference to his personal and assumed feelings of the Palestinian situation. However, this content is only effective (persuasive) if these heterogeneous experiences are drawn together into a skillful array, accomplished only by integration.

One may still ask, how is the hearer persuaded by integration, i.e. what predicates its acceptance? We have established that when an artist makes a predication, or series of predications, upon their experiential reality in a way that is skillfully integrative, this 
integrative inflection becomes effective in that it moves the individual along the cultural continua. Here, we can argue that the movement of an individual along cultural continua is likewise affected tacitly. The program of the artistic endeavor is tacit integration by skill, and similarly its efficacy may be attributed to a tacit recognition of that skill. That is to say, the hearer responds to a poem in a way that unconsciously recognizes the tacit integrative endeavor of the poet. The poet offers an experiential narrative, one that is skillfully articulated and made up of the cultural-historical contexts that are relevant to the hearer. When effective, the hearer is essentially accepting the narrative of the artist. This does not occur when hearer is a passive receiver of narrative, but rather when poem/narrative is dialogic. It requires acceptance, performed by the hearers, negotiated within their own experience. In some sense it is conscious and must be so, however it is laced with the unconscious. Thus, it is a mutually constructed dialogic act that recreates the persuasion of the original poem in the hearer.

This leads to the interesting question of cognitive predilections towards integration. Following Gabora, I argue that human cognition consists of two types, "diffusely activating a diversity of memory locations, is conductive to associative thought; obscure (but potentially relevant) properties of the situation thus come into play. Focused attention is conductive to analytic thought because memory activation is constrained enough to zero in and manipulate the most defining properties" (289. Emphasis added). The integrative practices of narrative and metaphor (poetry) are paradigmatic examples of associative thought, as the ability to construct a narrative depends on the ability to make connections between conceptual spaces. This is the exploitation of the 'intertextual gap' (Briggs \& Bauman), which allows for different constructions to play with the associative spaces 
between concepts. This intertextual play creates, "disorder, heterogeneity, and textual open-endedness, as well as order, unity, and boundedness" (Briggs \& Bauman 164). This implies that new concept formation is intrinsic upon other concept formations drawn from our own experience; the only way I ascertain the constituents of a concept is by relating it to others. In this way, it is possible to argue that the human mind effectively creates fractal conceptual narratives as a means of navigating reality; concepts are built on associated concept formations, which are a complex array of experiential memories. Though these concepts may be momentarily self-sufficient, they are not bounded or fixed, but in fact are open to a fluid association and dissociation in order to create new meaning. Thus, human cognition is built on integrative narrative, in the sense that it coheres experiences into meaningful 'events' or 'acts' that lead to an understanding of the 'whole', however the integration is essentially open-ended. It is unsurprising, then, to find that the human mind unconsciously, tacitly, works towards new integrative experience in the form of poetry, and is able to respond to it.

Interesting here is the emphasis on experiential memory to associative (even analytic to a lesser extent) cognitive functions. Though unsurprising, this conclusion implies that poetry will draw on the recognition of the experiential point of existential contact between the poet and the audience. This becomes more enforced when considering the scope of experience that the Palestinians can mutually recognize in one another. One of Darwish's most famous works 'ilā ${ }^{\circ}$ umī (To my mother), the work melodized and sung at his symbolic funeral, is exemplary of this type of experiential recognition. 


\begin{tabular}{|c|c|}
\hline āḥinnu `ilā knubzi ’ ummī & I long for my mother's bread \\
\hline wa-qahwati ${ }^{\circ}$ ummī & And my mother's coffee \\
\hline wa-lamsati ${ }^{\circ} \mathrm{umm}_{\overline{\mathrm{l}}}$ & And my mother's touch \\
\hline wa-takburu fiyya 't-ṭufūlatu & My childhood grows within me \\
\hline yawman calā șadri yawmi & Day after day \\
\hline 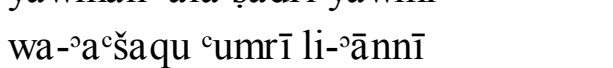 & I love my life because \\
\hline ’idā muttu & If I died, \\
\hline oākjjalu & I would be embarrassed \\
\hline min dami ${ }^{\supset} u m \bar{i}$ & by my mother's tears \\
\hline kudininī oidā cuddtu yawmān & Take me, if one day I return, \\
\hline wa-šāḥhạān li-hudbik & As a veil for your lashes \\
\hline wa-ḡutṭ̂i ciẓāmī bi-`oušbin & And cover my bones with grass \\
\hline tcammada min țuhri kcabik & Baptized by the purity of your heel \\
\hline wa-šuddi wa-tāàqī & And fasten my bonds \\
\hline bi-kֵușlati ša ${ }^{c} a r i n$ & With a lock of hair \\
\hline bi-kֵayyațin yilawwaḥu fi dīili tawbik & $\begin{array}{l}\text { With a piece of thread that trails } \\
\text { in the train of your dress }\end{array}$ \\
\hline casānī `āṣīru ১ilahān & Maybe I'd become a god \\
\hline 'ilahān `āṣīru & Agod I'd become \\
\hline ’idā mā lamstu qarārat qalbik & If I touched the depths of your heart \\
\hline ḍ̣caīnī oidāa mā rajcattu & Put me, if I return, \\
\hline wa-qūdān bi-tanawari nārik & As fuel in your cooking stove, \\
\hline wa-ḥabli ḡasīli calā saț̣i dārik & As a clothes line on your rooftop \\
\hline li-’ānn̄̄ faqadtu 'l-waqūfa & For I have lost resolve \\
\hline bi-dūni șalāti nahārik & Without your daily prayer \\
\hline harmitu faruddī najūma 'l-tafülati & I have grown decrepit: \\
\hline & Give me back the stars of childhood \\
\hline hatā 'ušārik & That I may join \\
\hline șiḡāra '1-caṣāfiri & The young birds \\
\hline darba '1-rajūca & On the return route \\
\hline li-cuš ointazāāik & To the nest of your waiting. \\
\hline
\end{tabular}

The experiential points of contact in the poem; bread, mother's touch, coffee, stove, clothing line, daily prayer etc. are conceptual formations that intrinsically recognize the existence of those same experiences in the audience of Palestinians. These meanings become dialogic when considering the cognition of conceptual formations; 
mother's bread for Darwish undoubtedly is constructed from a specific set of cultural 'artifacts'; the smell, the color, the shape of a kitchen. For another individual, 'mother's bread' is a different concept in that it is constructed from a different set of associated concepts and experiences. Thus, the signification of meaning is dialogic because it relies on recognition of a fundamental similarity between the two different sets of experiences.

Since the array of contextual historical circumstances is infinite and idiosyncratic, this integration must be localized in the experiential whole of the poet who produces the poem; Darwish and the Palestinian context. In this way, the integration of the whole becomes recognizable, particularly by those who share contextual circumstance and move along sets of discourse continua/socioideologies. Cultural continua are not hermetically sealed entities, but rather a sprawling cascade of conceptual association to which some may be closer to the discursive locus (which in our case is the poetic utterance) than others. The poet has the ability to integrate the cascade of conceptual linkages into a finely woven cloth; every conceptual point weaves and entwines with those around it, signifying a certain way of forming and understanding these concepts and negotiating personal experience with distillation into an integrated whole. From this, it can be argued that truly great art can be recognized cross-culturally. The complexity of discursive practice makes the ability to integrate dissonant experiences into a conceptual scheme valuable and truly skillful:

The word, directed towards its object, enters a dialogically agitated and tension-filled environment of alien words, valuejudgments and accents, weaves in and out of complex 
interrelationships, merges with some, recoils from others, intersects with yet a third group; and all this may crucially shape discourse, may leave a trace in all its semantic layers, may complicate its expression and influence its entire stylistic profile (Bakhtin 276).

If Bakhtin's words, poetic in their own right, display anything, it is the amazing complexity of the semantic domain. There is no neutral language; cultural continua are milieu of conceptual creation, recreation, and dialogue. This complexity offers firm evidence, not only for the necessity of the unconscious as a tacit integrator of experience, but of its real presence in poetic efficacy.

Thus, it is clear that the reason Darwish's poetry is fundamentally historical, even in a work that does not outright mention any historical event as such. Nevertheless, references to the mundane aspects of lived experience tease, weave, and pull at certain culturally contingent strands within the Palestinian context; experiences which are approximately recognized across the wider community and lead to their negotiation and acceptance. The fact of Darwish's lived experience of the 1948 and 1967, as well as the continually reaffirmation of those events as a vital discourse of modern Palestinian living, mark his poetic work as actualizing historical integration. Narrative building, as a means of bringing the past into the present through a diachronic alignment of motifs and concepts, is essentially the practice seen here. It is derived from this tacit ability to integrate the dissonant experience of the past into a sublime and cogent form. It is this skill that grants such power to seemingly quaint cultural productions to affect great change in the present and future behavior of individuals. 


\section{Conclusion:}

The efficacy of poetry in the Palestinian context derives from both the ability of poetry to create an integrated narrative that is dialogically actualized in an understanding of both past and present experiences and by the particularly traumatic experiences of the Palestinian people. This leads to a greater need for understanding and a reformation of that past, a performative response that creates new meaning, inflected on the present. As a means of creating historical events, poetry as integrative practice skillfully create narrative in the wake of heteroglossia: fluid conceptual formations become signified in new ways and pulled into a string of cogency. This does not imply that poetry makes concepts static or stagnant.

Indeed, the understandings of al-Nakba and 1967 are continually renewed and negotiated, adding to the overall fluidity of the conceptual space. What poetry can and does do is create novel concept associations; even though understanding of these events are renewed and changed, this only re-enforces the sociality of these events. Integrative practices of poetry can be seen as playful in this sense. A poet can skillfully move about the contextual space, resignifying already present concepts and even creating new ones through novel associations. The overall effect of these movements is to first of all create a certain history, in the sense of a diachronic narrative. This narrative necessarily works from the subjective orientation of the present; it serves to inform present discourses and to negotiate current occurrences. Given that the Palestinian existence is still largely caught up in the events of the 20th century, it is unsurprising that it is these histories that are constantly enacted, affirmed, changed, and negotiated. 


\section{Works Cited}

Al Jazeera. "Palestinian Poet Darwish Dies". 2008. Web.

Anderson, Benedict. Imagined Communities: Reflections on the Origin and Spread of Nationalism. Verso, 1991. Print

Antoon, Sinan. "Mahmud Darwish's Allegorical Critique of Oslo". Journal of Palestine Studies. Vol. 31, No. 2 (Winter 2002), pp. 66-77. University of California Press, 2002. Web.

Armbrust, Walter. "The Trickster in Egypt's January 25th Revolution." Comparative Studies in Society and History, 55(4):834-864. 2012. Web.

Asad, Talal. "The Idea of an Anthropology of Islam". The Social Philosophy of Ernest Gellner, Eds. John A. Hall and Ian Charles Jarvie, 381-403. Amsterdam and Atlanta: Rodopi, 1996. Print.

Bakhtin, M.M. The Dialogic Imagination: Four Essays. Translated by Michael Holquist and Carly Emerson. University of Texas Press Slavic Series, 1982. Print.

Bateson, Gregory. Steps to an Ecology of Mind. The University of Chicago Press, 1972. Print.

Baxandall, Michael. Painting and Experience in 15th century Italy. Oxford University Press, 1972. Print.

Bauman, Richard. Verbal Art as Performance. Waveland Press, 1984. Print.

Baumgarten, Helga, "The Three Faces of Palestinians Nationalism, 1948-2008”. Journal of Palestinian Studies. Vol. 34 No. 4 (Summer 2005). Web.

Berliner, David "The Abuses of Memory: Reflections on the Memory Boom in Anthropology", Anthropological Quarterly, 78(1): 197211. 2005. Web.

Briggs, Charles L., and Richard Bauman. "Genre, Intertextuality, and Social Power", Journal of Linguistic Anthropology, Vol. 2 (No. 2): 131-172. 1992. Web.

Caton, Steven. Peaks of Yemen I Summon. University of California Press, 1990. Print. 
Cleveland, William L. and Martin Bunton. A History of the Modern Middle East. Fourth Edition. Westview Press, 2009. Print.

Fernandez, James. Persuasion and Performances. Indiana University Press, 1986. Print.

Frangeih, Bassam. Modern Arabic Poetry: Vision and Reality in Traditions, Modernity and Postmodernity in Arabic Literature. Brill, 2000. Print.

Gabora, Liane. "Mind”, Eds. R. A. Bentley, H. D. G. Maschner, and C. Chippendale, Handbook of Theories and Methods in Archaeology, Altamira Press, Walnut Creek CA, 2007. 283296.

Geertz, Clifford. Islam Observed. University of Chicago Press, 1971. Print.

Gelvin, James. The Modern Middle East: A History. Second Edition, Oxford University Press, 2008. Print.

Gelvin, James. The Arab Revolts. Oxford University Press, 2011. Print.

Ghanem, As'ad. Palestinian Politics After Arafat: A Failed National Movement. Indiana University Press, 2010. Print.

Hourani, Albert. A History of the Arab Peoples. Harvard University Press, 1991. Print.

Ibrahim, Youssef M. "Palestinian Critics Accuse Arafat Of Secret Concessions to Israelis". New York Times. 1993. Web.

Jayyusi, Salma Khadra. Foreword to Mahmoud Darwish, Exile's Poet: Critical Essays. Interlink Books, 2007. Print.

Johnson, Mark. Moral Imagination: Implications of Cognitive Science For Ethics. Chicago, University of Chicago Press, 1993. Print.

Kress, G. "Thinking about the Notion of 'Cross-Cultural' from a Social Semiotic Perspective”. Language and Intercultural Communication, 12(4): 369-385. 2012. Web.

Lakoff George and Mark Johnson. "Metaphors in Everyday Language". The Journal of Philosophy, Vol. 77, No. 8 (1980): 453-486. Web. 
Mahmood, Saba. Politics of Piety: The Islamic Revival and the Feminist Subject. Princeton: Princeton University Press, 2005. Print.

Masquelier, Adeline. Prayer Has Spoiled Everything: Possession, Power, and Identity in an Islamic Town of Niger. Durham: Duke University Press, 2001. Print.

Mattawa, Khaled. When the Poet Is a Stranger: Poetry and Agency in Tagore, Walcott, and Darwish. Duke University, 2009. Web.

Middle East Research and Information Project. "The Oslo Accords". http://www.merip.org/palestine-israel_primer/oslo-accords-palisr-prime.html. 2001. Web.

Polanyi, Michael. Knowing and Being. London, Routledge \& K. Paul, 1969. Print.

Sacks, Sheldon. On Metaphor. University of Chicago Press. 1979. Print.

Shahin, Mariam. Palestine: A Guide. Chastleton Travel, 2007. Print.

Reich, Bernard. Arab-Israeli Conflict and Conciliation: A Documentary History. Greenwood Press, 1996. Print.

Turner, Victor. Forrest of Symbols: Aspects of Ndembu Ritual. Cornell University Press, 1967. Print.

Zivkovic, Marko. Serbian Dreambook: National Imaginary in the Time of Milosevic. Indiana University Press, 2011. Print. 
Aaron Eldridge is a $\mathrm{U}$ of A alumnus, currently working on his postgraduate studies at the Institute of Social and Cultural Anthropology, University of Oxford. His research interests include politics, revolution, and civil disobedience; political economy; religion, secularism, and the state; language, art, and power; as well as the Middle East, Egypt and the Levant.

afeldrid@ualberta.ca, aaron.eldridge@anthro.ox.ac.uk 